\title{
The social power of trade unions in the new market economies: why is it in decline?
}

\begin{abstract}
Trade unions in the new market economies in Europe have already been playing their roles in the political, economic, social and sometimes cultural transitions for more than twenty years. Sometimes they have had to take painful decisions, in the course of which they have been confronted with obstacles. If workers are not very satisfied with their trade unions, the main question is the identity of the most important reasons for that - are they external or internal to the trade unions? The new challenges to trade unions, caused by globalisation and European integration, require more radical internal changes than was the case in the early 1990s. The priorities, approaches, structures and styles of trade union leaders are, in contrast, similar to those inherited from the late nineteenth and early twentieth centuries. Ultimately, the decline in trade union influence has been caused rather more by their slow and difficult adaptation to the technological, economic and demographic changes afoot than by the crisis and the difficulties of protecting an older workforce and old working conditions.
\end{abstract}

Keywords: trade unions, transition, capacity, challenges, industrial relations, information technology, globalisation, political engagement, privatisation, labour laws, working practices, decentralisation, organisation and membership, atypical workers

\section{Introduction}

Trade unions from central and east European countries have played an important role in the whole transition from totalitarian society with a centralised economy to democracy and the market economy. They used to be (and they still are) one of the main pillars of reviving civil society in such countries and, in some situations, they have even adopted the role of multi-functional actors. However, currently trade unions have many problems, including the decline of their membership and influence, and they are facing plenty of challenges and difficulties in the implementation of their goals. If most workers are not particularly satisfied with their trade unions, the main question is what are the most important reasons for that - are they external or internal to the trade unions themselves?

Some of the problems of trade unions in central and eastern Europe are particularly related to the specific issues faced by post-communist societies, even in those countries which are already members of the European Union and NATO. At the same time, there are many challenges to trade union activity, as well as to industrial relations as a whole, for trade unions from central and eastern Europe - and also for trade unions from 
western Europe and other countries with market economies and democratic governments (i.e. countries which are affiliated to the Organisation for Economic Co-operation and Development). This is caused by there being a new industrial relations environment, influenced by the information society; globalisation; the appearance of new markets in the global economy; stronger competition; and by the changes taking place in the workforce.

\section{The main role of trade unions in the new market economies}

Trade unions in the new market economies in Europe have already participated in the political, economic, social and sometimes even cultural transitions taking place in their countries. Sometimes, they have had to take very painful decisions and they have also been confronted with challenging obstacles.

In the early $1990 \mathrm{~s}$, most trade unions in transition countries were either the old trade unions seeking to reform themselves and/or new trade unions appearing under the transitions. Both of them have had to made difficult choices since post-communist societies have had to make many transformations at one and the same time: transition in political systems, from totalitarian to democratic and pluralist governments; transition from centralised planned economies to market economies; changes in many areas of social policies; changes in the attitudes and values of society and citizens; while also, for some countries, national identities were obtaining a new quality. The changes, mainly the political ones, have been summarised by Kohl and Platzer (2004) as follows: institutional transition; representation transition; and behavioural transition.

In most countries, there was a process of a re-assembling (to some extent) of the pluralist character of the trade union movement which had been the case prior to the Second World War (Gardawski et al, 2012: see, in particular, the Foreword by Vandaelle). In the process, in most countries, the patterns of trade unions and industrial relations of democratic countries with market economies (mainly from western Europe) were researched and attempts made at implementing some of their characteristics. Some of the features of the western models have been successfully accepted by most of the trade unions in transition countries; however, the post-communist system of industrial relations has not been able to re-create any one of the 'western' models in its entirety. The reasons for this are mainly related to the quite different environment - the toocomplicated transitions in economics, legislation and politics was a situation simply not previously known in history.

The main areas of trade union policy-making were faced with many difficulties; some of these have been successfully overcome, but others are still causing problems and difficulties as regards the protection of working people. Some of the main areas of trade union policy-making are summarised in the following sub-sections.

\section{Trade unions, party politics and the main state institutions}

Most trade unions in post-communist countries have proclaimed their independence of political parties. In the early 1990s, there were contradictions between 'old' and 'new' trade unions, especially in Poland, Bulgaria and also in Hungary. The main dilemma was not, however, based on ideological differences. The dilemma is defined 
by the choice between denial and consent; between radical change and the strength to change while retaining some level of continuity. It is already difficult to define the extent to which the old trade unions have been transformed and the extent to which the new trade unions have inherited/accepted some of the characteristics of the bureaucracies of old communist trade union systems.

In various countries, several models of relationships with political parties have been accepted. There have been attempts at more closed relationships with political parties (both with former communist parties and with some newly-established democratic parties with left, centre or even centre-right orientations), as well as attempts at the creation of new labour parties based on trade union support. In most cases, the attempts at establishing labour parties have not been particularly successful. The current relationships between trade unions and political parties are quite different: over a period of more than twenty years, even the parties have changed. In most cases, trade unions usually stay at some distance from the parties.

Currently, the main political differences between trade unions are narrow, the main differences being much more related to strategy and tactics. In Bulgaria, the Confederation of Independent Trade Unions in Bulgaria (KNSB) has, for a long time, been much more focused on partnership (despite the orientation of the government and the employers) compared to the Confederation of Labour 'Podkrepa', which was more focused on protest actions and strikes. Subsequent to the beginning of the new millennium, there have been various situations: sometimes the places of the two confederations have changed, or both confederations have had similar views. However, there is already a much greater degree of co-ordination between the confederations. Nevertheless, in Bulgaria, like in other post-communist countries, many sectoral trade unions have separated themselves from the confederations because they wanted to be 'neutral', while many members have even left the trade unions, blaming them in the context of their political prejudices and in attempts to play their own political role.

\section{Economic policy and privatisation}

The economic transformations, privatisation and restructuring have been among the most significant policy areas for most trade unions. In general, privatisation has not been good news for trade union members although, in some cases, it was the only choice (where, for example, the other alternative was bankruptcy). It was not possible to oppose the process of privatisation in general, as far as private property is a pillar of democracy. However, civil society, and trade unions in particular, have not have sufficient capacity to control the implementation of justice and the fairness of the process. At the same time, it has also not been possible to avert the major and painful social consequences. Some special models, such as worker-management buy-outs and socalled mass (voucher) privatisation, were supported by trade unions as they could be used as a means of preserving jobs; however, the position is that not only successful stories have resulted.

Concerning restructuring, this has been even more painful than privatisation, but trade unions have not been able either to find alternatives to the way in which it has been defined, or to persuade governments to come up with such alternatives. 
Currently, some of the public sectors in Bulgaria, such as railways, postal services and others, need to be restructured, but there is a level of tension because the strategies presented by the government are not clear and are not supported by social activities.

The result of privatisation and restructuring has been that many jobs have been lost although, in some cases, new jobs have been created. This has also led to a decline in trade union membership.

\section{Changes in labour laws}

In the late 1990s and in the early years of the new century, labour law has been changed and trade unions have had to express their views. There have been some victories and some failures. On the one hand, changes have been made regarding the implementation of the labour and social standards of the International Labour Organisation, the Council of Europe and the European Union, which have supported the improvement of laws, especially labour laws. On the other hand, some changes regarding the implementation of 'flexibility', especially those made in the last few years, have not been welcomed by many workers or by the trade unions. Trade unions have resisted some of the changes, but they have gone ahead. In some countries (like Romania) some changes regarding trade union and other workplace rights have been made which have restricted trade union power.

\section{Long and painful reforms in social policies and institutions}

At the same time, changes in the social insurance law have sought the improvement of these systems, bearing in mind also the course of demographic trends. In most countries, changes in the laws have been made while there have also been institutional changes in the pensions and healthcare insurance systems. There are differences between countries but, in general, the increase in the retirement age and the required length of service for pensions purposes has not been welcomed by most workers - or by a large part of the population. In some cases, trade unions have resisted the changes, especially where already-agreed provisions have been changed after a short time (as in Bulgaria); but, in fact, they have not been able to stop the process, as pensions and also, sometimes, healthcare systems have usually needed additional financial support.

At the same time, the public sectors in some countries, including in the spheres of education, healthcare and others, have required additional reforms, which have often been painful as restructuring includes cutting jobs. This could also continue to provoke new problems for trade unions.

\section{Organisational issues}

Among the problems inhibiting the development of trade union activity and industrial relations have been their internal organisational changes. There have been many splits caused both by political differences, dissatisfaction with policies and also, in many cases, by the attitudes of union leaders. At the same time, there have been many problems in the co-ordination and direction of the representation of various interests. Trade unions are changing too slowly, especially in terms of their structures and approaches in workplaces. In many cases, they have not been able to provide opposition 
in an appropriate way to new employers in private companies. The result has been that the motivation for membership has declined and the new workforce, especially new generations, have not found anything of use in the trade unions.

\section{Summary}

Ultimately, trade union development in the transition period could be characterised in the following ways:

- trade unions from central and eastern Europe have tried to accept some elements of European models of trade union activity and industrial relations. However, only some of them could be implemented, and then only partially

- in most of the new EU member states, as well as in the candidate countries, the practical implementation of the basic principles of industrial relations, which are common to most EU member states (European Commission, 2008), has had many difficulties to confront. National and sectoral levels of social dialogue have been promoted in most countries, and workplace rights have been put into the law, but even freedom of association could sometimes scarcely be implemented. The coordination of collective bargaining, and the provision of information and consultation in workplaces, are still at their beginning

- the lack of a more clear and stronger acquis communautaire in labour law and social policy, and especially in industrial relations at EU level, is an obstacle to the better implementation of workers' rights and the development of stronger trade unions in the new EU member states.

New challenges to trade unions

Together with the challenges of the transition, new challenges to trade unions have also appeared since the late 1990s. These have been caused by globalisation and European integration processes. The new conditions require more radical changes inside trade unions than was the case in the early 1990s. Some of the main challenges are summarised in the following sub-sections:

\section{Challenges from economics, companies and labour}

- technological changes, causing the appearance of new production processes, new forms of work organisation and, sometimes, whole new sectors, new enterprises and new jobs; and creating also new requirements for human resources

- changes in the market and in the mobility of capital, which are bringing new forms of economic organisation, including networks of enterprises; increases in the number and scope of multinational businesses; the relocation of units and the outsourcing of operations; and the establishment of many new small and micro-enterprises, and others

- financial and structural crises already becoming transnational and it being difficult to avoid them

- the changes mentioned above are leading often to the use of new forms of employment, like posted workers; employment via agencies for temporary work; trans-border workers; migrant workers; homeworkers and teleworkers; dependent and independent self-employed contractors and others. In addition, greater levels 
of flexibility are being sought in contracts, in terms of working time, workplaces and work organisation

- all these economic and technological changes are premising changes in the qualities of the workforce (level of education, capacities, age and values); while, in addition, a multicultural structure of personnel at enterprise/company level is already not an exception.

\section{Challenges from social and political processes}

- there are already symptoms of the decline of the welfare state in the 'old' member states of the EU and in other democratic and economically-advanced countries

- there are trends towards a demographic crisis (mainly in terms of the ageing of the population), both in Europe and in other economically-advanced countries with market economies; at the same time, trans-border and trans-continental migration has increased

- furthermore, changes in the culture and values of society and its citizens may be observed; for instance, new generations usually have new values, and employees from the new service industries and sectors using new technologies are usually rather more individualist than collectivist-oriented, while their level of solidarity is different.

Challenges from new legislation and practices in terms of social dialogue and worker representation

- the acceptance of EU directives and the implementation of new practices of information, consultation and (in some cases) participation, involving all workers at enterprise level and at the level of multinational companies

- the increase in the use of transnational company agreements, codes of conduct, company charters, declarations and others

- the increase in importance of the European social dialogue and of European and international framework agreements

- the acceptance by many large companies of the policies and practices of corporate social responsibility.

\section{Summary}

At the same time, the priorities, approaches, structures and styles of the leadership of trade unions are, in general, still rather similar to those which have been inherited from the late nineteenth and early twentieth century. The decline in trade union influence has been caused rather more by their slow and agonising adaptation to the technological, economic, demographical and cultural changes which are underway than by the crisis, the painful changes in social policies and by the difficulties in protecting the old workforce and former working conditions.

Plenty of examples could be mentioned, including among them:

- difficulties in organising workers in new companies

- decline in trade union membership

- decline in the scope of collective bargaining, especially of sectoral and national bargaining 
- increase in unsuccessful strike activity

- difficulties in the co-ordination of industrial relations and worker representation in multinational companies

- the appearance of clear differences in the interests of, and even contradictions between, workers from various professions, sectors and enterprises, as well as between the trade unions representing them

- a lack of trade union capacity to organise atypical workers and workers from new enterprises and sectors

- a lack of trade union capacity to work together and to co-ordinate their activity with other civil society organisations and the new social movements.

\section{Main problems and possible strategies for change}

The lack of new capacity among trade unions could be expressed as a result of many trends in their activity which may be observed both in new and in old EU member states, as well as in other European countries. However, in post-communist countries the problems are more visible, since trade union experience is usually not as long and their resources are often weaker. Such a conclusion might also be illustrated by several typical trends in trade union activity:

- some trade unions are still focused on the national level instead of adapting themselves to the decentralisation of industrial relations

- some trade unions (especially those in the new EU member states and in candidate countries) still prefer to communicate with the government (ministries and local government offices) instead of focusing their dialogue on employers, despite the observable de-regulation of labour standards. Furthermore, trade unions also still rather prefer tripartite partnership, even though the importance of bipartite partnerships has increased both at national and at EU levels

- many trade unions are still strongly focused mainly on the traditional workforce instead of seeking to organise new workers

- some trade unions make too many efforts at causes which are either already lost (like some dimensions of pensions reform) or which are not of the most significant importance to the majority of workers (for example, some highly political issues, as far as they do not exactly concern labour)

- some trade unions (both from old and new EU member states) are focused mainly on national issues, often avoiding EU-level and global issues; at the same time, the importance of European and global issues has increased

- in many new EU member states, and also in some of the old ones, there is strong resistance to information and consultation practices (both at national and transnational levels), as well as to issues of corporate social responsibility expressed by the trade union side. In fact, such trade unions have not been able to exploit the priorities of new industrial relations practices

- some trade unions do not have the capacity to use an individual approach in enterprises or companies; however, old forms of 'collectivism' have already declined

- in many post-communist countries, both in EU member states and in candidate countries, trade unions do not have the capacity to use new approaches while, sometimes, even the use of new technology is difficult; at the same time, regarding 
the engagement of new categories of worker, trade unions do need to use new approaches and the new means provided by technological developments (the internet and others)

- most trade unions express the desire to retain at any cost the old structures and mechanisms of work, while there is a fear of change and a resistance to it; at the same time, it is usually not possible to organise some of the new workers without using new structures.

\section{Conclusion}

In general, most of the problems and trends mentioned above usually provoke questions like 'Do I need to be a trade union member?' or even 'Do we need trade unions?' Most trade unions from central and eastern Europe, and also other democratic trade unions, are challenged by a dilemma - either of returning to authentic, traditional forms of trade unionism or of finding a new way, by changing their policies, actions, approaches and structures. There are some voices articulating the former, but it is clear that the new age of 'globalisation' requires rather a new way than a reversion to the old.

\section{References}

European Commission (2008) Industrial relations in Europe 2008, report of European Commission DG Employment, Social Affairs and Equal Opportunities, September.

Galgóczi, B (2000) 'Industrial relations in Central Eastern Europe in the perspective of EU enlargement' in R. Hoffmann, O. Jacobi, B. Keller and M. Weiss (Eds.) Transnational Industrial Relations in Europe Hans-Böckler-Stiftung: Düsseldorf, pp. 177-189.

Gardawski J, A. Mrosowicki and J. Czarzasty (2012) Trade unions in Poland Report 123, ETUI: Brussels.

Градев, Г (2000) 'Демократичинят процес и синдикалната идентичност в преход’ (Gradev, G: The democratic process and the trade union identity in transition) in Българското синдикално движение-минало и настояще С.КНСБ, рр.154-170.

Kohl, H and H. W. Platzer (Eds.) (2004) Industrial Relations in Central and Eastern Europe. Transformation and integration: a comparison of the eight new EU member states ETUI: Brussels.

Morisse-Schilbach, M and K. Schroeder (2006) Europaeische Idaentitet - was veraendert die Osteweiterung? Erforlgsaussichten von Idaentitetsbuildung in einem Gemeinschaft im Wandel February, Friedrich-Ebert-Stiftung http://www.fes-olineacademie.de.

Todorov, A (2011) Bulgarian Political Culture and Civic Participation FriedrichEbert-Stiftung: Sofia. 